\title{
König se grootste werk ooit
}

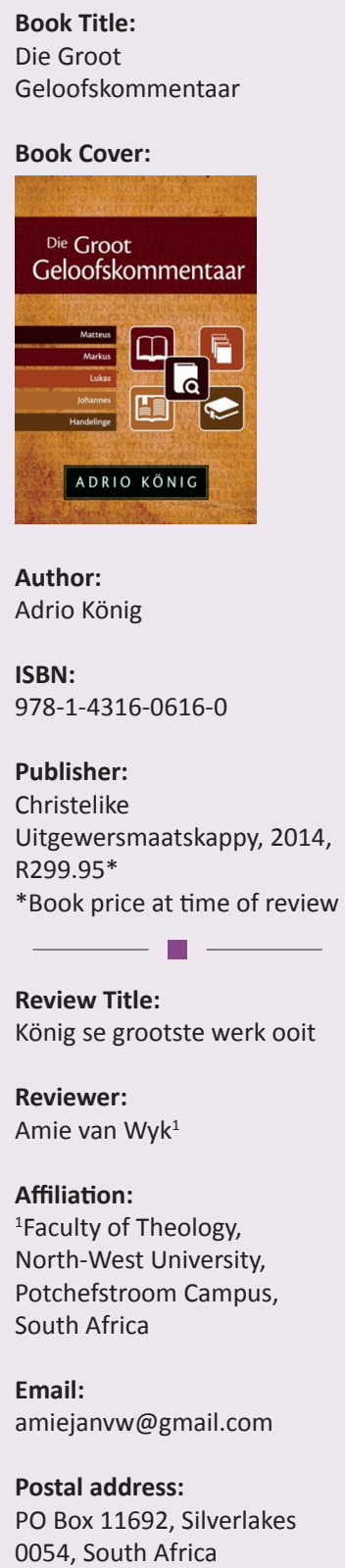

Author:

Adrio König

ISBN:

978-1-4316-0616-0

Publisher:

Christelike

Uitgewersmaatskappy, 2014,

R299.95*

*Book price at time of review -

Review Title:

König se grootste werk ooit

Reviewer:

Amie van $W_{y k}{ }^{1}$

\section{Affiliation:}

${ }^{1}$ Faculty of Theology,

North-West University,

Potchefstroom Campus,

South Africa

Email:

amiejanvw@gmail.com

Postal address:

PO Box 11692, Silverlakes

0054, South Africa

How to cite this book review: Van Wyk, A., 2015, 'König se grootste werk ooit', In die Skriflig 49(1), Art. \#1985, 2 pages. http://dx.doi. org/10.4102/ids.v49i1.1985

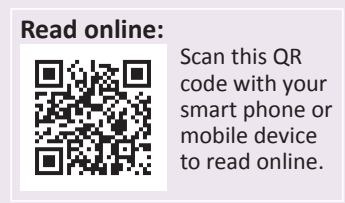

König vermeld in die voorwoord van sy boek dat dit 'die grootste werk is wat ek ooit in my lewe aangepak het' - en dit kan inderdaad gesê word van 'n boek wat 567 bladsye beslaan. Die boek is nie soos 'n gewone kommentaar geskryf nie, maar word as 'n geloofskommentaar op die vier evangelies en Handelinge aangebied.

Die boek bevat 'n inleidende hoofstuk van meer as 100 bladsye wat oor die Jesusboodskap van die vier evangelies handel waar die skrywer by die klassieke verstaan van die persoon en werk van die Here Jesus Christus aansluit. Dit val op dat König die koninkryk van God as sentrale tema in die prediking van Jesus sien (bl. 51-64, passim). Ook die opstanding of opwekking van Jesus ontvang besondere aandag en nadruk (bl. 89-93, 107-109, 118-123, 126-132). Volgens die outeur tas die kleiner verskille rondom die opstandingsverhale nie die wesenlike inhoud van die evangelie aan nie (bl. 122-123). Die verhale oor die opstanding of opwekking vorm die eerste inhoud van die evangelieverkondiging, terwyl die kruisevangelie later bygevoeg word (vgl. Hand; bl. 105-106). Die historiese betroubaarheid van die evangelies is baie belangrik (bl. 124).

Hierna word die vier evangelies afsonderlik behandel, beginnende by die oudste, naamlik dié van Markus. Elke evangelie begin met die behandeling van vier vrae: wie?, waar?, wanneer?, en vir wie? Wat Markus betref, word die volgende aspekte nader toegelig: die 'evangelie'; geloof; die Messiasgeheim; Jesus se lyding en sterwe; en die slot.

Die behandeling van Matteus is veel langer en beslaan byna 100 bladsye. Ná die vier aanvangsvrae word die volgende aspekte aan die orde gestel: die evangelie vir Israel; die Bergrede (met 'n verklaring van die Onse Vader-gebed); die slinkse plan teen Jesus; grepe uit Matteus; en die vervulling van profesieë.

By Lukas gaan dit oor die volgende sake: die breedheid van die evangelie; die randfigure; die redding van verlorenes; die verklaring van gelykenisse; die doderyk en die hel; die sagte menslike sy van Lukas; raakpunte tussen Lukas en Paulus; enkele opvallende uitsprake; en Lukas, die 'praise and worship'-Evangelie.

Ook aan die Evangelie van Johannes word meer as 100 bladsye bestee en die volgende fokusareas kom in die gesigsveld: Is dit 'n ander soort evangelie?; die heerlike, verheerlikte, goddelike Jesus; die verhouding tussen Jesus en die Vader; die verhouding tussen Jesus en ons; die mens as beeld van God; die lyding van Jesus; Johannes en Paulus; en nog meer eie-goed van Johannes.

Die bespreking van Handelinge beslaan die meeste bladsye. Na die aanvangsvrae word na die volgende sake gekyk: die doel van Handelinge; die evangelie in Handelinge (die preke); historiese betroubaarheid; die Heilige Gees; die doop; die skeiding van Jode en Christene; aanhalings uit die Ou Testament; die Septuagint; hemel, hemelvaart en wêreldbeeld; en nog belangrike sake in Handelinge. 'n Samevattende slothoofstuk ontbreek egter.

Eerstens 'n paar positiewe, waarderende opmerkings: Die eerste positiewe opmerking is dat ons hier met 'n omvattende studie oor die vier evangelies en Handelinge te doen het wat ryk is aan gegewens en wat telkens nuwe horisonne van die Skrifboodskap open. Daar is werklik nêrens gedeeltes wat nie boeiend is nie. Soms is daar lang besprekings oor aanverwante sake, soos byvoorbeeld oor die mens as beeld van God (bl. 372-389).

'n Tweede saak wat ek besonder waardeer, is König se aansluiting by die klassieke vertolking van die kern van die evangeliese boodskap en sy afwysing van die hiperkritiese benadering daarvan waardeur dit eintlik ontkrag word. Daar is wesenlike sake soos die kruis en opstanding van Jesus (bl. 197, 450, passim) wat onvervangbaar en onmisbaar is indien die evangelie nog 
evangelie wil bly. Waar dít sowel as die besondere betekenis wat die Nuwe-Testamentiese skrywers daaraan heg, wegval, is daar geen goeie boodskap meer oor nie. So ook wat die wonderwerke van Jesus betref. Die moderne wetenskaplike wêreldbeeld verander niks aan ons christelike geloof nie (bl. 526-530).

'n Derde aspek wat vermelding verdien, is die 'heilshistoriese' lesing waarvolgens König die boodskappe van die evangelies en Handelinge ter sprake bring en waarin onder andere op die doel van die skrywer en die eerste lesers van die teks gefokus word. Dit bied die outeur die geleentheid om telkens die aandag op die verskillende nuanses wat by die skrywers na vore kom, te vestig. Terselfdertyd vrywaar dit hom om die evangeliste van teenstrydighede te beskuldig.

Die vierde uitsonderlike faset is die outeur se herhaaldelike verwysing na die oorspronklike Hebreeuse en Griekse woorde. Hy vind nogal dikwels aansluiting by die 1953-Bybelvertaling - soms met kritiese opmerkings oor die 1983-vertaling.

Vyfdens het ek waardering vir die afwysing van 'n voorspoedsteologie wat veral in Amerika in evangeliese kringe 'n welige teelaarde vind. (Daar was onlangs 'n mediaberig van 'n evangelis wat sy gemeente opgeroep het om sy vliegtuig met 'n nuwe straler te vervang.) Die navolging van Christus bring dikwels lyding mee. Dit was die vroeë christene se ervaring en groot christenvervolging kom vandag ook wydverspreid in veral die Midde-Ooste en Asiatiese lande voor.

Vervolgens drie kritiese opmerkings (al sou daar meer gemaak kon word): Die eerste raak 'n aspek van König se Skrifbeskouing. Hy is lief daarvoor om telkens - ook in sy ander geskrifte - na die feit te verwys dat 'n bepaalde gedagte wat in die Skrif voorkom, 'ontwikkel' het (bl. 55, 407). Veral in die intertestamentêre periode vind daar 'n 'ontwikkeling' plaas, byvoorbeeld oor die ontstaan van bose geeste (bl. 519). Die term ontwikkeling is problematies, want die volgende vrae ontstaan: Wié ontwikkel die gedagte(s)?; Hoe gesaghebbend is die ontwikkelde gedagte?; Vind die ontwikkeling onder inspirasie van die Gees plaas?; Is dit nie teologies sinvoller om die klassieke term openbaring aan te wend (wat König soms wel doen; bl. 385) en dan ook van 'voortgaande openbaring' te praat nie? Alleen deur 'openbaring' weet ons dat Jesus die Messias en Seun van die lewende God is (Matt 16:17). Dit is alleen deur 'n 'openbaring' van Jesus Christus dat Paulus die evangelie van God se genade in Christus ontdek het (Gal 1:11-12).

'n Terloopse waarneming in hierdie verband is König se opmerking oor die feit dat die Septuagint (dit is die vertaling van die Ou Testament in Grieks deur Jode 200 jaar v.C.) wat vir 1500 jaar die Ou Testament van die christelike kerk was, 'belangrike implikasies vir die manier waarop ons die gesag van die Bybel verstaan' het (bl. 519), omdat hierdie vertaling die Ou Testament 'gemessianiseer' het. Tog word hierdie 'belangrike implikasies' nie uitgespel nie en word daar met die opmerking dat hierdie gegewe 'op geen manier ons geloof bedreig nie' volstaan (bl. 520).

'n Tweede opmerking raak die eskatologie van die $\mathrm{Ou}$ Testament, veral die aspek van 'lewe na en anderkant die dood'. Volgens König ken die Ou Testament nie eintlik die gedagte van lewe na en anderkant die dood nie en is dit baie sterk op die aardse en tydelike lewe ingestel (bl. 455-460). Die Ou Testament fokus inderdaad sterk op die hiernoumaalse lewe (vgl. Ps 6:6; 30:10; 86:11, 12; 115:17; Jes 38:18, 19). Dit gaan vir die Ou-Testamentiese gelowige oor 'n lewe in gemeenskap met en in diepe afhanklikheid van die lewende Verbondsgod. Tog is daar in die Ou Testament, veral in die latere geskrifte, enkele verwysings na 'n eskatologiese verwagting, ook na en anderkant die dood. König verwys ook na sommige hiervan (bv. Ps 73:24; Jes 25:5; 26:19, Eseg 37; Dan 12:2). Die onderskeie hemelvaarte van Henog en Elia is ook ' $n$ gesaghebbende aanduiding hiervan. (Daarom kan die Nuwe Testament ook rustig na die verskyning van Elia en Moses saam met Christus op die berg van verheerliking verwys; Matt 17:3). In die Ou Testament breek daar dus ook enkele ligstrale van 'n eskatologiese heilstyd deur vir gelowiges in gemeenskap met die lewende God wat hemel en aarde geskape het.

'n Derde opmerking is in verband met die NuweTestamentiese eskatologie. König beklemtoon dat die eintlike eindbestemming van die gelowige nie 'in die hemel' sal wees nie, maar op die nuwe aarde (bl. 94, 419-421, 530). Hierdie benadering is ' $n$ verstaanbare reaksie op 'n eensydige hemelverlange wat veral in metodistiese kringe te vinde is. Ek dink in hierdie verband aan Willie Jonker wat die digter Izak de Villiers geïnspireer het om die lied Ek sien ' $n$ nuwe hemel kom, ' $n$ aarde nuut en vry oor Openbaring 21 te dig waarin daar ook na die nuwe aarde verwys word. Indien die fokus egter slegs op die 'nuwe aarde' geplaas word - want dit word 'hemel op aarde'- ontstaan die vraag hoe ons die verwysing na die 'nuwe hemel' moet interpreteer. Indien 'hemel' egter in die lig van Genesis 1 verstaan word as die totale werklikheid bo die aarde, dui die 'nuwe hemel en aarde' op die vernuwing van die totale heelal. Die nuwe heelal sal dan die uiteindelike woonplek van die gelowiges wees. (Dit maak ook sin vanuit 'n wetenskaplike hoek gesien.)

König het aan ons 'n uiters lesenswaardige boek voorsien wat ons teologiese kennis verbreed en ons geloofsinsig verdiep. Dit is die moeite werd om 'n grondige studie van hierdie boek te maak. 